\title{
ANALISIS TINGKAT KEPUASAN PELANGGAN TERHADAP PELAYANAN PELABUHAN MUARA ANGKE
}

\author{
Fadliyah Nurbaya ${ }^{1}$, Winoto Hadi ${ }^{2}$ \\ Email :fadliyahnurbaya@gmail.com ${ }^{1}$, winoto@unj.ac.id ${ }^{2}$ \\ ${ }_{2}^{1}$ Prodi D III Transportasi, Fakultas Teknik - Universitas Negeri Jakarta \\ Prodi D III Transportasi, Fakultas Teknik - Universitas Negeri Jakarta
}

\begin{abstract}
Abstrak. Pelabuhan memiliki peranan penting dalam melayani kegiatan di negara kepulauan salah satunya Indonesia. Tersedianya pelayanan yang terdapat didalam pelabuhan bagi pengguna jasa pelabuhan menjadi hal yang harus diperhatikan oleh pemerintah yang diharapkan mampu berusaha untuk memenuhi tingkat kinerja pelayanan pelabuhan yang diharapkan terhadap tingginya tingkat kepuasan pengguna jasa pelabuhan di DKI Jakarta, maka pengguna jasa pelabuhan akan semakin percaya dengan kebijakan-kebijakan Pemprov DKI Jakarta dalam bidang perhubungan khususnya di bagian dinas perhubungan Unit Pengelola Angkutan Perairan dan Kepelabuhanan. Pelayanan yang terdapat didalam pelabuhan yang dapat dirasakan pengguna jasa pelabuhan secara langsung adalah pelayanan yang terdapat di pelabuhan penumpang. Salah satu pelabuhan penumpang di DKI Jakarta yang diharapkan dapat memberi tingkat kepuasan yang tinggi adalah Pelabuhan penumpang Muara Angke. Teknik penelitian ini menggunakan metode survey untuk pengambilan sampel data, analisis pembahasannya menggunakan analisis deskriptif, metode Gap dengan cara menghitung tingkat kesesuaian dan diagram kartesius. Hasilnya, dinilai pengguna jasa pelabuhan masih belum maksimal dalam memberikan pelayanan dalam pelabuhan seperti tidak ada pelayanan ketersediaan informasi fasilitas kesehatan penanganan darurat dan tidak ada pelayanan kenyamanan fasilitas untuk pelayanan kesehatan yang bertujuan mengantisipasi jika terjadinya keadaan darurat masalah kesehatan, sehingga pengguna jasa pelabuhan segera mendapat pertolongan pertama.
\end{abstract}

Kata kunci: kepuasan pelanggan, gap, diagram kartesius, pelayanan pelabuhan

\begin{abstract}
Abstrac, The port has an important role in serving activities in one of the archipelago countries, Indonesia. The availability of services contained in ports for users of port services must be considered by the government which is excepted to be able to try to meet the level of port service performance expected of the high level of satisfaction of users of port service in DKI Jakarta. The policy of the DKI Jakarta Provincial Government in the field of transportation, especially in the department of transportation, the Unit for Management of water and Port Transportation. The services contained in the port that can be directly felt by users of port services are those that are available at the passenger port. One of the passanger ports in DKI Jakarta that is expected to provide a high level of satisfaction is Muara Angke Passanger Port. This research technique uses survey methods for sampling data, analysis of the discussion using descriptive analysis, gap method by calculating the level of suitability and cartesius diagram. As a result, users of port services are still not maximal in providing services in ports such as there is no service to provide information on emergency health care facilities and there is no convenience service for health services aimed at anticipating healt emergencies, so that users of port service immediateky receive help first.
\end{abstract}

Keyword: Customer Satisfaction, Gap, Cartesius Diagram, Port Service.

\section{A. PENDAHULUAN}

Pelabuhan memiliki peranan penting dalam melayani kegiatan di negara kepulauan salah satunya Indonesia. Tersedianya pelayanan yang terdapat didalam pelabuhan bagi pengguna jasa pelabuhan menjadi hal yang harus diperhatikan oleh pemerintah yang diharapkan mampu berusaha untuk memenuhi tingkat kinerja pelayanan pelabuhan yang diharapkan terhadap tingginya tingkat kepuasan pengguna jasa pelabuhan di DKI Jakarta, maka pengguna jasa pelabuhan akan semakin percaya dengan kebijakan-kebijakan Pemprov DKI Jakarta dalam bidang perhubungan khususnya di bagian Dinas Perhubungan Unit Pengelola Angkutan Perairan dan Kepelabuhanan.

Pelayanan yang terdapat didalam pelabuhan yang dapat dirasakan pengguna jasa pelabuhan secara langsung adalah pelayanan yang terdapat di pelabuhan penumpang. Salah satu pelabuhan penumpang di DKI Jakarta yang diharapkan dapat memberi tingkat kepuasan yang tinggi adalah Pelabuhan Muara Angke, yang mana merupakan pelabuhan yang dikelola oleh Unit Pengelola Angkutan Perairan dan Kepelabuhanan. Pelabuhan Muara Angke merupakan pelabuhan penumpang yang melayani penduduk pulau dan penumpang warga lokal atau wisatawan antar pulau yang menghubungkan Jakarta dengan pulau-pulau sekitarnya. namun dinilai pengguna jasa pelabuhan masih belum maksimal dalam memberikan pelayanan dalam pelabuhan seperti tidak ada pelayanan ketersediaan informasi fasilitas kesehatan penanganan darurat dan tidak ada pelayanankenyamanan fasilitas untuk pelayanan kesehatan yang bertujuan mengantisipasi jika terjadinya keadaan darurat masalah kesehatan, sehingga pengguna jasa pelabuhan segera mendapat pertolongan pertama. Tidak ada kenyamanan fasilitas / tempat untuk merokok seperti pada saat 
peneliti melakukan survey, terdapat petugas yang menegur penumpang yang merokok di area dermaga, sehingga perlu adanya identifikasi untuk mengukur tingkat kepuasan pelanggan terhadap pelayanan dengan mengetahui harapan dan kinerja pelayanan yang diterima pengguna jasa yang menggunakan pelabuhan muara angke. sehingga kepuasan tersebut dapat menjadi indikator untuk menilai kinerja pelayanan Pelabuhan Muara Angke.

\section{B. METODE PENELITIAN}

Metode ini menggunakan metode pengumpulan data baik berupa dengan cara studi literatur dan survey dengan melakukan penyebaran angket yang terstruktur melalui kuesioner. Data primer diperoleh dengan pengamatan langsung di lapangan, wawancara dengan staf pelayanan, dan kuesioner yang disebarkan kepada pengguna jasa pelabuhan, dan diperoleh 65 data yang dapat dianalisisi. Penelitian ini menggunakan atribut pelyanan dalam Peraturan Menteri Perhubungan nomor 119 tahun 2015 tentang perubahan PM nomor 37 tahun 2015 tentang Standar Pelayanan Penumpang Angkutan Laut dan disesuaikan dengan kondisi lapangan pelabuhan sebagai berikut.

Tabel 1. Pelayanan Beserta Dimensinya

\begin{tabular}{|c|c|c|}
\hline Dimensi & No. & Pelayanan \\
\hline \multirow[t]{2}{*}{ Reliability } & 1 & $\begin{array}{l}\text { Kemudahan untuk mendapat tiket (tersedia loket dan waktu pelayanan } \\
\text { maksimum } 5 \text { menit) }\end{array}$ \\
\hline & 2 & Kejelasan informasi kedatangan dan keberangkatan kapal \\
\hline \multirow{2}{*}{ Assurance } & 3 & Ketersediaan informasi peralatan penyelamatan ketika dalam bahaya \\
\hline & 4 & Ketersediaan informasi fasilitas kesehatan penanganan darurat \\
\hline \multirow{9}{*}{ Tangible } & 5 & Kenyamanan ruang tunggu penumpang \\
\hline & 6 & Kenyamanan pintu masuk menuju peron \\
\hline & 7 & Kenyamanan toilet \\
\hline & 8 & Kenyamanan tempat ibadah \\
\hline & 9 & Kenyamanan sumber cahaya \\
\hline & 10 & Kenyamanan fasilitas sirkulasi udara \\
\hline & 11 & Kenyamanan fasilitas kebersihan (tempat sampah) \\
\hline & 12 & Kenyamanan fasilitas untuk pelayanan kesehatan \\
\hline & 13 & Kenyamanan fasilitas / tempat untuk merokok \\
\hline \multirow{7}{*}{ Empathy } & 14 & Kemudahan untuk mendapatkan informasi lintasan dan tariff \\
\hline & 15 & $\begin{array}{l}\text { Kemudahan untuk mendapat informasi waktu kedatangan dan keberangkatan } \\
\text { kapal }\end{array}$ \\
\hline & 16 & Kemudahan untuk mendapat perjalanan kapal dan layanan pengaduan \\
\hline & 17 & Kemudahan untuk mendapat informasi angkutan lanjutan \\
\hline & 18 & Kemudahan naik dan turun penumpang dari dan ke kapal \\
\hline & 19 & Ketersediaan fasilitas penyandang difabel \\
\hline & 20 & Ketersediaan fasilitas / ruangan khusus ibu menyusui \\
\hline \multirow{4}{*}{ Responsiveness } & 21 & Ketersediaan fasilitas keamanan dan ketertiban \\
\hline & 22 & Ketertiban naik dan turun penumpang dari dan ke kapal \\
\hline & 23 & Ketersediaan pos dan petugas keamanan \\
\hline & 24 & Ketersediaan informasi gangguan keamanan \\
\hline
\end{tabular}

Data karakteristik responden terdiri karakteristik responden berdasarkan data jenis kelamin, usia, pekerjaan, penghasilan perbulan, berapa kali menggunakan pelayanan Pelabuhan Muara Angke dan tujuan berpergian. Untuk penilaian kuesioner pelayanan sangat baik dengan nilai 4, baik dengan nilai 3, kurang baik dengan nilai 2, tidak baik dengan nilai 1.Teknik analisis data menggunakan metode gap analysis di mana dicari tingkat kesesuaian, gap, dan diagram kartesius. 


\section{HASIL DAN PEMBAHASAN}

Karakteristik Responden dimana pengambilan sampel dilakukan selama Praktek Kerja Lapangan, di Pelabuhan Muara Angke. Pengambilan sampel dilakukan pada hari biasa dan hari libur. karakteristik responden berdasarkan data jenis kelamin, usia, pekerjaan, penghasilan perbulan, berapa kali menggunakan pelayanan Pelabuhan Muara Angke dan tujuan berpergian, disajikan pada tabel berikut ini.

\section{Tabel 2. Karakteristik Responden}

\begin{tabular}{|c|c|c|}
\hline Nama (Jenis Kelamin) & Laki-Laki & 35 \\
\hline & Perempuan & 30 \\
\hline & Total & 65 \\
\hline \multirow[t]{4}{*}{ Usia } & 20-30 tahun & 38 \\
\hline & 31-40 tahun & 23 \\
\hline & $41-50$ tahun & 4 \\
\hline & Total & 65 \\
\hline \multirow[t]{6}{*}{ Pekerjaan } & PNS & 8 \\
\hline & Pegawai swasta & 16 \\
\hline & Wiraswasta & 5 \\
\hline & Mahasiswa/Pelajar & 26 \\
\hline & Lainnya & 10 \\
\hline & $\overline{\text { Total }}$ & 65 \\
\hline \multirow{4}{*}{$\begin{array}{l}\text { Berapa kali menggunakan } \\
\text { pelayanan Pelabuhan } \\
\text { Muara Angke }\end{array}$} & 1-2 kali & 27 \\
\hline & 3-4 kali & 23 \\
\hline & $>5$ kali & 15 \\
\hline & Total & 65 \\
\hline \multirow[t]{4}{*}{ Tujuan bepergian } & Bekerja & 17 \\
\hline & Berkunjung & 20 \\
\hline & Lainnya & 28 \\
\hline & Total & 65 \\
\hline \multirow[t]{6}{*}{ Penghasilan perbulan } & Blm berpenghasilan & 18 \\
\hline & $1-3$ juta & 14 \\
\hline & $3,1-5$ juta & 18 \\
\hline & 5,1-6 juta & 9 \\
\hline & $>6$ juta & 6 \\
\hline & Total & 65 \\
\hline
\end{tabular}

Serta terdapat Uji validitas dan reliabilitas dilakukan untuk menguji kevalidan dan keandalan data kinerja dan harapan kepuasan pelanggan di Pelabuhan Muara Angke. Kuesioner dinyatakan valid apabila nilai $r$ hitung lebih besar dari $\mathrm{r}$ table dan untuk dinyatakan reliable apabila nilai $\mathrm{r}$ alpha lebih besar dari $\mathrm{r}$ table. Untuk memudahkan perhitungan uji validitas dan reliabilitas digunakan program SPSS versi 20. Berikut disajikan uji validitas dan reliabilitas menggunakan SPSS dari semua pertanyaan. 
Tabel 3. Validitas Pertanyaan Kinerja

\begin{tabular}{|l|l|l|l|}
\hline Pertanyaan & r hitung & r table & Pernyataan \\
\hline Pertanyaan 1 & 0.388 & 0.244 & Valid \\
\hline Pertanyaan 2 & 0.522 & 0.244 & Valid \\
\hline Pertanyaan 3 & 0.479 & 0.244 & Valid \\
\hline Pertanyaan 4 & 0.510 & 0.244 & Valid \\
\hline Pertanyaan 5 & 0.485 & 0.244 & Valid \\
\hline Pertanyaan 6 & 0.751 & 0.244 & Valid \\
\hline Pertanyaan 7 & 0.413 & 0.244 & Valid \\
\hline Pertanyaan 8 & 0.445 & 0.244 & Valid \\
\hline Pertanyaan 9 & 0.787 & 0.244 & Valid \\
\hline Pertanyaan 10 & 0.612 & 0.244 & Valid \\
\hline Pertanyaan 11 & 0.554 & 0.244 & Valid \\
\hline Pertanyaan 12 & 0.605 & 0.244 & Valid \\
\hline Pertanyaan 13 & 0.487 & 0.244 & Valid \\
\hline Pertanyaan 14 & 0.466 & 0.244 & Valid \\
\hline Pertanyaan 15 & 0.725 & 0.244 & Valid \\
\hline Pertanyaan 16 & 0.810 & 0.244 & Valid \\
\hline Pertanyaan 17 & 0.727 & 0.244 & Valid \\
\hline Pertanyaan 18 & 0.639 & 0.244 & Valid \\
\hline Pertanyaan 19 & 0.607 & 0.244 & Valid \\
\hline Pertanyaan 20 & 0.661 & 0.244 & Valid \\
\hline Pertanyaan 21 & 0.561 & 0.244 & Valid \\
\hline Pertanyaan 22 & 0.736 & 0.244 & Valid \\
\hline Pertanyaan 23 & 0.611 & 0.244 & Valid \\
\hline Pertanyaan 24 & 0.620 & 0.244 & Valid \\
\hline
\end{tabular}

Dari tabel tersebut diketahui bahwa nilai $r$ hitung kinerja lebih besar dari $r$ tabel, sehingga dapat dinyatakan bahwa semua pertanyaan pada kuesioner adalah valid.

Tabel 4. Validitas Pertanyaan Harapan

\begin{tabular}{|l|l|l|l|}
\hline Pertanyaan & r hitung & $\mathrm{r}$ table & Pernyataan \\
\hline Pertanyaan 1 & 0.465 & 0.244 & Valid \\
\hline Pertanyaan 2 & 0.500 & 0.244 & Valid \\
\hline Pertanyaan 3 & 0.523 & 0.244 & Valid \\
\hline Pertanyaan 4 & 0.571 & 0.244 & Valid \\
\hline Pertanyaan 5 & 0.430 & 0.244 & Valid \\
\hline Pertanyaan 6 & 0.730 & 0.244 & Valid \\
\hline Pertanyaan 7 & 0.522 & 0.244 & Valid \\
\hline Pertanyaan 8 & 0.501 & 0.244 & Valid \\
\hline Pertanyaan 9 & 0.602 & 0.244 & Valid \\
\hline Pertanyaan 10 & 0.559 & 0.244 & Valid \\
\hline Pertanyaan 11 & 0.621 & 0.244 & Valid \\
\hline Pertanyaan 12 & 0.569 & 0.244 & Valid \\
\hline Pertanyaan 13 & 0.433 & 0.244 & Valid \\
\hline Pertanyaan 14 & 0.352 & 0.244 & Valid \\
\hline Pertanyaan 15 & 0.691 & 0.244 & Valid \\
\hline Pertanyaan 16 & 0.705 & 0.244 & Valid \\
\hline Pertanyaan 17 & 0.634 & 0.244 & Valid \\
\hline Pertanyaan 18 & 0.662 & 0.244 & Valid \\
\hline Pertanyaan 19 & 0.528 & 0.244 & Valid \\
\hline Pertanyaan 20 & 0.617 & 0.244 & Valid \\
\hline Pertanyaan 21 & 0.501 & 0.244 & Valid \\
\hline Pertanyaan 22 & 0.677 & 0.244 & Valid \\
\hline Pertanyaan 23 & 0.583 & 0.244 & Valid \\
\hline Pertanyaan 24 & 0.651 & Valid \\
\hline
\end{tabular}


Dari tabel tersebut diketahui bahwa nilai $r$ hitung harapan lebih besar dari $r$ tabel, sehingga dapat dinyatakan bahwa semua pertanyaan pada kuesioner adalah valid.

Tabel 5. Uji Reliabilitas Pertanyaan Kinerja Dan Harapan

\begin{tabular}{|l|l|l|l|}
\hline Pertanyaan & $\mathrm{r}$ alpha & $\mathrm{r}$ table & Pernyataan \\
\hline Semua pertanyaan kinerja & 0.750 & 0.6 & Reliable \\
\hline Semua pertanyaan harapan & 0.747 & 0.6 & Reliable \\
\hline
\end{tabular}

Dari tabel tersebut diketahui bahwa $\mathrm{r}$ alpha lebih besar dari $\mathrm{r}$ tabel, sehingga dapat dinyatakan semua pertanyaan kinerja dan harapan adalah reliable.

Untuk mengetahui seluruh penilaian responden atas semua pertanyaan pelayanan dapat dilihat pada tabel berikut.

Tabel 6. Hasil Penilaian Pelanggan Terhadap Kinerja Pelayanan

\begin{tabular}{|l|l|l|l|l|l|}
\hline \multirow{2}{*}{ Pertanyaan } & Penilaian & \multicolumn{2}{l}{ Jumlah } \\
\cline { 2 - 5 } & 4 & 3 & 2 & 1 & \multirow{2}{*}{ J } \\
\hline Pertanyaan 1 & 0 & 27 & 37 & 1 & 65 \\
\hline Pertanyaan 2 & 9 & 38 & 9 & 9 & 65 \\
\hline Pertanyaan 3 & 1 & 24 & 14 & 26 & 65 \\
\hline Pertanyaan 4 & 1 & 19 & 9 & 36 & 65 \\
\hline Pertanyaan 5 & 6 & 42 & 7 & 10 & 65 \\
\hline Pertanyaan 6 & 7 & 33 & 13 & 12 & 65 \\
\hline Pertanyaan 7 & 0 & 23 & 22 & 20 & 65 \\
\hline Pertanyaan 8 & 8 & 22 & 23 & 12 & 65 \\
\hline Pertanyaan 9 & 12 & 25 & 16 & 12 & 65 \\
\hline Pertanyaan 10 & 7 & 36 & 15 & 7 & 65 \\
\hline Pertanyaan 11 & 1 & 24 & 23 & 17 & 65 \\
\hline Pertanyaan 12 & 0 & 10 & 12 & 43 & 65 \\
\hline Pertanyaan 13 & 0 & 6 & 22 & 37 & 65 \\
\hline Pertanyaan 14 & 10 & 35 & 11 & 9 & 65 \\
\hline Pertanyaan 15 & 12 & 34 & 10 & 9 & 65 \\
\hline Pertanyaan 16 & 0 & 35 & 15 & 15 & 65 \\
\hline Pertanyaan 17 & 3 & 12 & 27 & 23 & 65 \\
\hline Pertanyaan 18 & 8 & 37 & 16 & 4 & 65 \\
\hline Pertanyaan 19 & 3 & 7 & 23 & 32 & 65 \\
\hline Pertanyaan 20 & 0 & 23 & 19 & 37 & 65 \\
\hline Pertanyaan 21 & 5 & 29 & 8 & 24 & 65 \\
\hline Pertanyaan 22 & 16 & 17 & 7 & 3 & 65 \\
\hline Pertanyaan 23 & 16 & 606 & 387 & 438 & 65 \\
\hline Pertanyaan 24 & 4 & 129 & & 28 & 1560 \\
\hline Total & & 95 & \\
\hline
\end{tabular}

Berdasarkan tabel, jumlah total responden yang memberikan penilaian 4,3,2,1 terhadap kinerja pelayanan diketahui sebanyak $8 \%$ yang memberi penilaian 4, penilaian 3 sebanyak 39\%, penilaian 2 sebanyak 25\%. dan penilaian sebanyak $28 \%$. 
Tabel 7. Hasil Penilaian Pelanggan Terhadap Harapan Pelayanan

\begin{tabular}{|c|c|c|c|c|c|}
\hline \multirow{2}{*}{ Pertanyaan } & \multicolumn{4}{|c|}{ Penilaian } & \multirow{2}{*}{ Jumlah } \\
\hline & 4 & 3 & 2 & 1 & \\
\hline Pertanyaan 1 & 28 & 37 & 0 & 0 & 65 \\
\hline Pertanyaan 2 & 48 & 17 & 0 & 0 & 65 \\
\hline Pertanyaan 3 & 26 & 39 & 0 & 0 & 65 \\
\hline Pertanyaan 4 & 21 & 44 & 0 & 0 & 65 \\
\hline Pertanyaan 5 & 49 & 16 & 0 & 0 & 65 \\
\hline Pertanyaan 6 & 41 & 24 & 0 & 0 & 65 \\
\hline Pertanyaan 7 & 24 & 41 & 0 & 0 & 65 \\
\hline Pertanyaan 8 & 31 & 34 & 0 & 0 & 65 \\
\hline Pertanyaan 9 & 38 & 27 & 0 & 0 & 65 \\
\hline Pertanyaan 10 & 44 & 21 & 0 & 0 & 65 \\
\hline Pertanyaan 11 & 26 & 39 & 0 & 0 & 65 \\
\hline Pertanyaan 12 & 11 & 54 & 0 & 0 & 65 \\
\hline Pertanyaan 13 & 7 & 58 & 0 & 0 & 65 \\
\hline Pertanyaan 14 & 46 & 19 & 0 & 0 & 65 \\
\hline Pertanyaan 15 & 47 & 18 & 0 & 0 & 65 \\
\hline Pertanyaan 16 & 36 & 29 & 0 & 0 & 65 \\
\hline Pertanyaan 17 & 17 & 48 & 0 & 0 & 65 \\
\hline Pertanyaan 18 & 46 & 19 & 0 & 0 & 65 \\
\hline Pertanyaan 19 & 11 & 54 & 0 & 0 & 65 \\
\hline Pertanyaan 20 & 10 & 55 & 0 & 0 & 65 \\
\hline Pertanyaan 21 & 28 & 37 & 0 & 0 & 65 \\
\hline Pertanyaan 22 & 45 & 20 & 0 & 0 & 65 \\
\hline Pertanyaan 23 & 56 & 9 & 0 & 0 & 65 \\
\hline Pertanyaan 24 & 22 & 43 & 0 & 0 & 65 \\
\hline Total & 758 & 802 & 0 & 0 & 65 \\
\hline
\end{tabular}

Berdasarkan tabel, jumlah total responden yang memberikan penilaian 4,3,2,1 terhadap harapan pelayanan diketahui sebanyak 49\% yang memberi penilaian 4, penilaian 3 sebanyak 51\%, penilaian 2 dan 1 sebanyak $0 \%$. 
Untuk melihat skor penilaian pelanggan terhadap pelayanan, Responden yang memberikan penilaian sangat baik atau penilaian 4 pada pertanyaan, maka jumlah responden dikalikan 4, yang memberikan penilaian baik atau penilaian 3 pada pertanyaan, maka jumlah responden dikalikan 3, yang memberikan penilaian kurang baik atau penilaian 2, maka jumlah responden dikalikan 2 dan yang memberikan penilaian tidak baik atau penilaian 1, maka jumlah responden dikalikan 1. Berikut disajikan tabel skor penilaian pelanggan terhadap kinerja pelayanan dan harapan pelayanan.

Tabel 8. Skor Penilaian Pelanggan Terhadap Kinerja Pelayanan

\begin{tabular}{|l|l|l|l|l|l|}
\hline \multirow{2}{*}{ Pertanyaan } & Penilaian & \multicolumn{3}{l}{ J } & \multirow{2}{*}{ Jumlah } \\
\cline { 2 - 5 } & 4 & 3 & 2 & 1 & \\
\hline Pertanyaan 1 & 0 & 81 & 74 & 1 & 156 \\
\hline Pertanyaan 2 & 34 & 114 & 18 & 9 & 177 \\
\hline Pertanyaan 3 & 4 & 72 & 28 & 26 & 130 \\
\hline Pertanyaan 4 & 4 & 57 & 18 & 36 & 115 \\
\hline Pertanyaan 5 & 24 & 126 & 14 & 10 & 174 \\
\hline Pertanyaan 6 & 28 & 99 & 26 & 12 & 165 \\
\hline Pertanyaan 7 & 0 & 69 & 44 & 20 & 133 \\
\hline Pertanyaan 8 & 32 & 66 & 46 & 12 & 156 \\
\hline Pertanyaan 9 & 48 & 75 & 32 & 12 & 167 \\
\hline Pertanyaan 10 & 28 & 108 & 30 & 7 & 173 \\
\hline Pertanyaan 11 & 4 & 72 & 46 & 17 & 139 \\
\hline Pertanyaan 12 & 0 & 30 & 24 & 43 & 97 \\
\hline Pertanyaan 13 & 0 & 18 & 44 & 37 & 99 \\
\hline Pertanyaan 14 & 40 & 105 & 22 & 9 & 176 \\
\hline Pertanyaan 15 & 48 & 102 & 20 & 9 & 179 \\
\hline Pertanyaan 16 & 0 & 105 & 22 & 15 & 150 \\
\hline Pertanyaan 17 & 12 & 36 & 54 & 23 & 125 \\
\hline Pertanyaan 18 & 32 & 111 & 32 & 4 & 179 \\
\hline Pertanyaan 19 & 12 & 21 & 46 & 32 & 111 \\
\hline Pertanyaan 20 & 0 & 27 & 38 & 37 & 102 \\
\hline Pertanyaan 21 & 20 & 69 & 26 & 24 & 139 \\
\hline Pertanyaan 22 & 64 & 87 & 16 & 12 & 179 \\
\hline Pertanyaan 23 & 64 & 117 & 14 & 3 & 198 \\
\hline Pertanyaan 24 & 16 & 51 & 32 & 28 & 127 \\
\hline Total & 516 & 1818 & 774 & 438 & 3546 \\
\hline
\end{tabular}

Berdasarkan tabel, skor penilaian pelanggan terhadap kinerja pelayanan, responden yang memberikan penilaian 4 pada pertanyaan adalah 516, yang memberikan penilaian 3 pada pertanyaan adalah 1818, yang memberikan penilaian 2 adalah 774 dan yang memberikan penilaian 1 adalah 438. 
Tabel 9. Skor Penilaian Pelanggan Terhadap Harapan Pelayanan

\begin{tabular}{|l|l|l|l|l|l|}
\hline \multirow{2}{*}{ Pertanyaan } & Penilaian & \multicolumn{4}{l|}{ Jumlah } \\
\cline { 2 - 5 } & 4 & 3 & 2 & 1 & \\
\hline Pertanyaan 1 & 112 & 111 & 0 & 0 & 223 \\
\hline Pertanyaan 2 & 192 & 51 & 0 & 0 & 243 \\
\hline Pertanyaan 3 & 104 & 117 & 0 & 0 & 221 \\
\hline Pertanyaan 4 & 84 & 132 & 0 & 0 & 216 \\
\hline Pertanyaan 5 & 196 & 48 & 0 & 0 & 244 \\
\hline Pertanyaan 6 & 164 & 72 & 0 & 0 & 236 \\
\hline Pertanyaan 7 & 96 & 123 & 0 & 0 & 219 \\
\hline Pertanyaan 8 & 124 & 102 & 0 & 0 & 226 \\
\hline Pertanyaan 9 & 152 & 81 & 0 & 0 & 233 \\
\hline Pertanyaan 10 & 176 & 63 & 0 & 0 & 239 \\
\hline Pertanyaan 11 & 104 & 117 & 0 & 0 & 221 \\
\hline Pertanyaan 12 & 44 & 162 & 0 & 0 & 206 \\
\hline Pertanyaan 13 & 28 & 174 & 0 & 0 & 202 \\
\hline Pertanyaan 14 & 184 & 57 & 0 & 0 & 241 \\
\hline Pertanyaan 15 & 188 & 54 & 0 & 0 & 242 \\
\hline Pertanyaan 16 & 144 & 87 & 0 & 0 & 231 \\
\hline Pertanyaan 17 & 68 & 144 & 0 & 0 & 212 \\
\hline Pertanyaan 18 & 184 & 57 & 0 & 0 & 241 \\
\hline Pertanyaan 19 & 44 & 162 & 0 & 0 & 206 \\
\hline Pertanyaan 20 & 40 & 165 & 0 & 0 & 205 \\
\hline Pertanyaan 21 & 112 & 111 & 0 & 0 & 223 \\
\hline Pertanyaan 22 & 180 & 60 & 0 & 0 & 240 \\
\hline Pertanyaan 23 & 224 & 27 & 0 & 0 & 251 \\
\hline Pertanyaan 24 & 88 & 129 & 0 & 0 & 217 \\
\hline Total & 3032 & 2406 & 0 & 0 & 5438 \\
\hline
\end{tabular}

Berdasarkan tabel, skor penilaian pelanggan terhadap harapan pelayanan, responden yang memberikan penilaian 4 pada pertanyaan adalah 3032, yang memberikan penilaian 3 pada pertanyaan adalah 2406 , yang memberikan penilaian 2 dan penilaian 1 adalah 0 .

Mengetahui seberapa besar pelanggan merasa puas terhadap kinerja perusahaan, dan seberapa pihak penyedia pelayanan memahami apa yang diinginkan pelanggan terhadap pelayanan yang mereka berikan.

Maka dapat menggunakan Pengukuran tingkat kesesuaian Rumus yang digunakan untung menghitung tingkat kesesuaian adalah:

$\mathrm{Tki}=\frac{\Sigma X}{\Sigma Y} \times 100 \%$ 
Tabel 10. Tingkat Kesesuaian

\begin{tabular}{|c|l|l|l|l|}
\hline No. & Pertanyaan & $\begin{array}{c}\text { Kinerja } \\
(\mathrm{X})\end{array}$ & $\begin{array}{c}\text { Harapan } \\
(\mathrm{Y})\end{array}$ & $\mathrm{Tki}(\%)$ \\
\hline 1 & $\begin{array}{c}\text { Kemudahan untuk mendapat tiket (tersedia loket dan } \\
\text { waktu pelayanan maksimum 5 menit) }\end{array}$ & 156 & 223 & 69.96 \\
\hline 2 & $\begin{array}{l}\text { Kejelasan informasi kedatangan dan keberangkatan kapal } \\
\text { Ketersiaan informasi peralatan penyelamatan ketika } \\
\text { dalam bahaya }\end{array}$ & 177 & 243 & 72.84 \\
\hline 4 & $\begin{array}{c}\text { Ketersediaan informasi fasilitas kesehatan penanganan } \\
\text { darurat }\end{array}$ & 115 & 216 & 58.82 \\
\hline 5 & Kenyamanan ruang tunggu penumpang & 174 & 244 & 71.31 \\
\hline 6 & Kenyamanan pintu masuk menuju peron & 165 & 236 & 69.92 \\
\hline 7 & Kenyamanan toilet & 133 & 219 & 60.73 \\
\hline 8 & Kenyamanan tempat ibadah & 156 & 226 & 69.03 \\
\hline 9 & Kenyamanan sumber cahaya & 167 & 233 & 71.67 \\
\hline 10 & Kenyamanan fasilitas sirkulasi udara & 173 & 239 & 72.38 \\
\hline 11 & Kenyamanan fasilitas kebersihan (tempat sampah) & 139 & 221 & 62.90 \\
\hline 12 & Kenyamanan fasilitas untuk pelayanan kesehatan & 97 & 206 & 47.09 \\
\hline 13 & Kenyamanan fasilitas / tempat untuk merokok & 99 & 202 & 49.01 \\
\hline 14 & $\begin{array}{c}\text { Kemudahan untuk mendapatkan informasi lintasan dan } \\
\text { tariff }\end{array}$ & 176 & 241 & 73.03 \\
\hline 15 & $\begin{array}{c}\text { Kemudahan untuk mendapat informasi waktu kedatangan } \\
\text { dan keberangkatan kapal }\end{array}$ & 179 & 242 & 73.97 \\
\hline 16 & $\begin{array}{c}\text { Kemudahan untuk mendapat perjalanan kapal dan layanan } \\
\text { pengaduan }\end{array}$ & 150 & 231 & 64.94 \\
\hline 17 & Kemudahan untuk mendapat informasi angkutan lanjutan & 125 & 212 & 58.96 \\
\hline 18 & Kemudahan naik dan turun penumpang dari dan ke kapal & 179 & 241 & 74.27 \\
\hline 19 & Ketersediaan fasilitas penyandang difabel & 111 & 206 & 53.88 \\
\hline 20 & Ketersediaan fasilitas / ruangan khusus ibu menyusui & 102 & 205 & 49.76 \\
\hline 21 & Ketersediaan fasilitas keamanan dan ketertiban & 139 & 223 & 62.33 \\
\hline 22 & Ketertiban naik dan turun penumpang dari dan ke kapal & 179 & 240 & 74.58 \\
\hline 23 & Ketersediaan pos dan petugas keamanan & 198 & 251 & 78.88 \\
\hline 24 & Ketersediaan informasi gangguan keamanan & 127 & 217 & 58.53 \\
\hline
\end{tabular}

Berdasarkan tabel, tingkat kesesuaian dari kinerja pelayanan dan harapan pelanggan terhadap pelayanan tertinggi adalah ketersediaan pos dan petugas keamanan. Sedangkan tingkat kesesuaian terendah dari kinerja pelayanan dan harapan pelanggan terhadap pelayanan adalah kenyamanan fasilitas untuk pelayanan kesehatan.

Untuk mengetahui mengenai tingkat kinerja atau kepuasan pelanggan dapat menggunakan Diagram Kartesius yang dimana diagram kartesius merupakan suatu bangun dibagi atas empat bagian yang dibatasi oleh dua buah garis yang berpotongan tegak lurus pada titik $(\mathrm{X}, \mathrm{Y})$ dimana $\mathrm{X}$ merupakan rata-rata tingkat kinerja atau kepuasan pelanggan seluruh faktor atau atribut dan $\mathrm{Y}$ adalah rata-rata dari skor rata-rata tingkat harapan seluruh faktor yang mempengaruhi kepuasan pelanggan.Berikut disajikan tabel nilai diagram kartesius berdasarkan skor rata-rata penilaian kinerja pelayanan atau sumbu $\mathrm{X}$, skor rata-rata penilaian harapan pelayanan atau sumbu $\mathrm{Y}$ dan gap. 
Tabel 11. Nilai Diagram Kartesius

\begin{tabular}{|l|l|l|l|}
\hline Pertanyaan & $\begin{array}{c}\text { Skor rata-rata penilaian kinerja } \\
\text { pelayanan/sumbu X }\end{array}$ & $\begin{array}{c}\text { Skor rata-rata penilaian harapan } \\
\text { pelayanan/sumbu Y }\end{array}$ & Gap \\
\hline 1 & 2.40 & 3.43 & 1.03 \\
\hline 2 & 2.72 & 3.74 & 1.02 \\
\hline 3 & 2.00 & 3.40 & 1.40 \\
\hline 4 & 1.77 & 3.32 & 1.55 \\
\hline 5 & 2.68 & 3.75 & 1.07 \\
\hline 6 & 2.54 & 3.63 & 1.09 \\
\hline 7 & 2.05 & 3.37 & 1.32 \\
\hline 8 & 2.40 & 3.48 & 1.08 \\
\hline 9 & 2.57 & 3.58 & 1.01 \\
\hline 10 & 2.66 & 3.68 & 1.02 \\
\hline 11 & 2.14 & 3.40 & 1.06 \\
\hline 12 & 1.49 & 3.17 & 1.68 \\
\hline 13 & 1.52 & 3.11 & 1.59 \\
\hline 14 & 2.71 & 3.71 & 1.00 \\
\hline 15 & 2.75 & 3.72 & 0.97 \\
\hline 16 & 2.31 & 3.55 & 1.24 \\
\hline 17 & 1.92 & 3.26 & 1.34 \\
\hline 18 & 2.75 & 3.71 & 0.96 \\
\hline 19 & 1.71 & 3.17 & 1.46 \\
\hline 20 & 1.57 & 3.15 & 1.58 \\
\hline 21 & 2.14 & 3.43 & 1.29 \\
\hline 22 & 2.75 & 3.69 & 0.94 \\
\hline 23 & 3.05 & 3.86 & 0.81 \\
\hline 24 & 1.95 & 3.34 & 1.39 \\
\hline
\end{tabular}

Berdasarkan skor rata-rata penilaian kinerja pelayanan atau sumbu X, skor rata-rata penilaian harapan pelayanan atau sumbu Y dan gap. Berikut adalah gambar diagram kartesius.

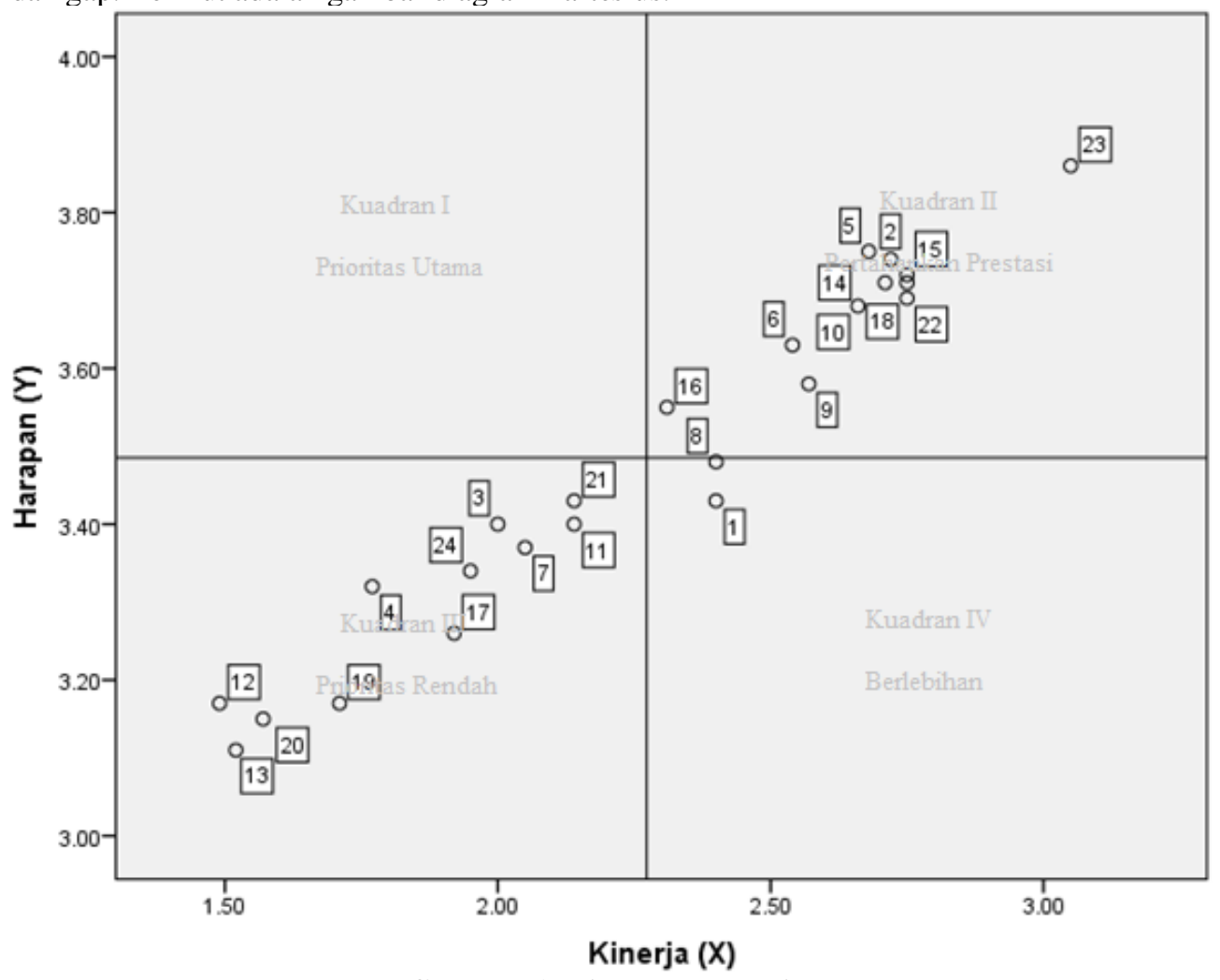

Gambar 1. Diagram kartesius

Dari gambar diagram kartesius dapat dijabarkan keterangan sebagai berikut. 
Tabel 12. Diagram Kartesius Dan Keterangan

\begin{tabular}{|c|c|c|c|c|}
\hline No. & Pertanyaan & $\mathrm{X}$ & $\mathrm{Y}$ & Keterangan \\
\hline 1 & $\begin{array}{l}\text { Kemudahan untuk mendapat tiket (tersedia loket dan } \\
\text { waktu pelayanan maksimum } 5 \text { menit) }\end{array}$ & 2.40 & 3.43 & Berlebihan \\
\hline 2 & $\begin{array}{l}\text { Kejelasan informasi kedatangan dan keberangkatan } \\
\text { kapal }\end{array}$ & 2.72 & 3.74 & Pertahankan prestasi \\
\hline 3 & $\begin{array}{l}\text { Ketersediaan informasi peralatan penyelamatan ketika } \\
\text { dalam bahaya }\end{array}$ & 2.00 & 3.40 & Prioritas rendah \\
\hline 4 & $\begin{array}{l}\text { Ketersediaan informasi fasilitas kesehatan penanganan } \\
\text { darurat }\end{array}$ & 1.77 & 3.32 & Prioritas rendah \\
\hline 5 & Kenyamanan ruang tunggu penumpang & 2.68 & 3.75 & Pertahankan prestasi \\
\hline 6 & Kenyamanan pintu masuk menuju peron & 2.54 & 3.63 & Pertahankan prestasi \\
\hline 7 & Kenyamanan toilet & 2.05 & 3.37 & Prioritas rendah \\
\hline 8 & Kenyamanan tempat ibadah & 2.40 & 3.48 & Berlebihan \\
\hline 9 & Kenyamanan sumber cahaya & 2.57 & 3.58 & Prioritas rendah \\
\hline 10 & Kenyamanan fasilitas sirkulasi udara & 2.66 & 3.68 & Pertahankan prestasi \\
\hline 11 & Kenyamanan fasilitas kebersihan (tempat sampah) & 2.14 & 3.40 & Prioritas rendah \\
\hline 12 & Kenyamanan fasilitas untuk pelayanan kesehatan & 1.49 & 3.17 & Prioritas rendah \\
\hline 13 & Kenyamanan fasilitas / tempat untuk merokok & 1.52 & 3.11 & Prioritas rendah \\
\hline 14 & $\begin{array}{l}\text { Kemudahan untuk mendapatkan informasi lintasan dan } \\
\text { tariff }\end{array}$ & 2.71 & 3.71 & Pertahankan prestasi \\
\hline 15 & $\begin{array}{c}\text { Kemudahan untuk mendapat informasi } \\
\text { kedatangan dan keberangkatan kapal }\end{array}$ & 2.75 & 3.72 & Pertahankan prestasi \\
\hline 16 & $\begin{array}{l}\text { Kemudahan untuk mendapat perjalanan kapal dan } \\
\text { layanan pengaduan }\end{array}$ & 2.31 & 3.55 & Pertahankan prestasi \\
\hline 17 & $\begin{array}{c}\begin{array}{c}\text { Kemudahan untuk mendapat informasi angkutan } \\
\text { lanjutan }\end{array} \\
\end{array}$ & 1.92 & 3.26 & Prioritas rendah \\
\hline 18 & $\begin{array}{l}\text { Kemudahan naik dan turun penumpang dari dan ke } \\
\text { kapal }\end{array}$ & 2.75 & 3.71 & Pertahankan prestasi \\
\hline 19 & Ketersediaan fasilitas penyandang difabel & 1.71 & 3.17 & Prioritas rendah \\
\hline 20 & Ketersediaan fasilitas / ruangan khusus ibu menyusui & 1.57 & 3.15 & Prioritas rendah \\
\hline 21 & Ketersediaan fasilitas keamanan dan ketertiban & 2.14 & 3.43 & Prioritas rendah \\
\hline 22 & Ketertiban naik dan turun penumpang dari dan ke kapal & 2.75 & 3.69 & Pertahankan prestasi \\
\hline 23 & Ketersediaan pos dan petugas keamanan & 3.05 & 3.86 & Pertahankan prestasi \\
\hline 24 & Ketersediaan informasi gangguan keamanan & 1.95 & 3.34 & Prioritas rendah \\
\hline
\end{tabular}

\section{KESIMPULAN}

Berdasarkan hasil pembahasan dapat disimpulkan sebagai berikut:

1. Berdasarkan analisis deskriptif didapatkan hasil bahwa tidak ada pelayanan yang tingkat kinerja pelayanan tersebut lebih rendah daripada tingkat harapan pelanggan terhadap pelayanan tersebut.

2. Pelayanan yang memiliki tingkat harapan dan kinerja yang tinggi atau baik dan hasilnya sangat memuaskan adalah pelayanan nomor 2, 5, 6, 10, 14, 15, 16,18, 22 dan 23 atau pelayanan kejelasan informasi kedatangan dan keberangkatan kapal (reliability), kenyamanan ruang tunggu, kenyamanan pintu masuk menuju peron, kenyamanan fasilitas sirkulasi udara (tangible), kemudahan untuk mendapatkan informasi lintasan dan tarif, kemudahan untuk mendapat informasi waktu kedatangan dan keberangkatan kapal, kemudahan untuk mendapat perjalanan kapal dan layanan pengaduan, kemudahan naik dan turun penumpang dari dan ke kapal (empathy), ketertiban naik dan turun penumpang dari dan ke kapal dan ketersediaan pos dan petugas keamanan (responsiveness).

3. Pelayanan yang memiliki tingkat harapan yang rendah dan kinerjanya juga dinilai kurang baik oleh pelanggan adalah pelayanan nomor $3,4,7,9,11,12,13,17,19,20,21$ dan 24 atau pelayanan ketersediaan informasi peralatan penyelamatan ketika dalam bahaya, ketersediaan informasi fasilitas kesehatan penanganan darurat (assurance), kenyamanan toilet, kenyamanan sumber cahaya, kenyamanan fasilitas kebersihan (tempat sampah), kenyamanan fasilitas untuk pelayanan kesehatan, kenyamanan fasilitas / tempat untuk merokok (tangible), kemudahan untuk mendapat informasi angkutan lanjutan, ketersediaan fasilitas penyandang difabel, ketersediaan fasilitas / ruangan khusus ibu menyusui (empathy), ketersediaan fasilitas keamanan dan ketertiban dan ketersediaan informasi gangguan keamanan (responsiveness).

4. Pelayanan yang memiliki tingkat harapan rendah menurut pelanggan akan tetapi memiliki kinerja yang baik, 
sehingga dianggap berlebihan oleh pelanggan adalah pelayanan nomor 1 dan 8 atau pelayanan kemudahan untuk mendapat tiket (tersedia loket dan waktu pelayanan maksimum 5 menit) dan kenyamanan tempat ibadah.

5. Berdasarkan hasil pengamatan langsung di lapangan dan terdapat beberapa komponen yang dikaitkan dengan 9 komponen logistik, maka hasil yang didapatkan sistem informasi berupa standar pelayanan minimum atau standar pelayanan penumpang angkutan laut di pelabuhan. Mengenai sistem fasilitas, yaitu semua fasilitas yang ada di pelabuhan dan sistem transportasi berupa kapal. Sistem pergudangan berupa terminal pelabuhan. Sistem pasokan atau supply berupa pengguna jasa pelabuhan atau penumpang. Sistem bongkar muat berupa kegiatan naik dan turun kapal. Sistem besaran berupa jumlah penumpang dan kecepatan kegiatan pelayanan. Sistem target yaitu menghasilkan tingkat kepuasan pelanggan.

\section{E. SARAN}

Berdasarkan kesimpulan yang telah dibuat, maka dapat diambil beberapa saran yang dapat dijadikan masukan, sebagai berikut:

1. Pihak penyedia jasa atau unit pengelola angkutan perairan dan kepelabuhanan harus lebih memperhatikan pelayanan yang disediakan.

2. Untuk pelayanan yang memiliki tingkat harapan dan kinerja yang tinggi atau baik dan hasilnya sangat memuaskan, pelayanan tersebut harus lebih di pertahankan kinerjanya.

3. Pelayanan yang dinilai kurang baik, seperti pelayanan pelayanan ketersediaan informasi peralatan penyelamatan ketika dalam bahaya, ketersediaan informasi fasilitas kesehatan penanganan darurat (assurance), kenyamanan toilet, kenyamanan sumber cahaya, kenyamanan fasilitas kebersihan (tempat sampah), kenyamanan fasilitas untuk pelayanan kesehatan, kenyamanan fasilitas / tempat untuk merokok (tangible), kemudahan untuk mendapat informasi angkutan lanjutan, ketersediaan fasilitas penyandang difabel, ketersediaan fasilitas / ruangan khusus ibu menyusui (empathy), ketersediaan fasilitas keamanan dan ketertiban dan ketersediaan informasi gangguan keamanan (responsiveness). Harus disediakan dengan baik oleh pihak penyedia jasa.

4. Semua yang pelayanan yang terkait dengan 9 komponen logistik, perlu diperbaiki agar menghasilkan pelayanan yang bersifat 3EP atau Efektif, Efisien, Ekonomis dan Produktif.

\section{F. DAFTAR PUSTAKA}

Hadi, Winoto. 2008. Studi Tingkat Layanan Terminal Bus Kampung Melayu Dilihat dari Sisi Pengguna. Jurnal Logistik D3 Transportasi UNJ Vol.1 No.2

Subekti, Sitti. 2017. Kepuasan Penumpang Terhadap Pelayanan Terminal Domestik di Bandar Udara Adi Sucipto Yogyakarta. Jakarta: Warta Penelitian Perhubungan Vol.29 No.2

Budianto, Duwi. 2013. Analisis Kepuasan Konsumen Terhadap Kualitas Pelayanan dan Harga Produk Dengan Menggunakan Metode Customer Satisfaction Index (CSI) dan Importance Performance Analysis (IPA). Pekanbaru.

Lie, Lewana Venna, Andreani, Fransisca. 2017. Analisis Gap Antara Harapan dan Persepsi Karyawan Tentang Keadilan Organisasi di PT Kali Jaya Putra. Surabaya: Agora Vol.5 No.1

Pemerintah Indonesia 2015. Peraturan Menteri Perhubungan nomor 119 tahun 2015 tentang perubahan PM nomor 37 tahun 2015 tentang Standar Pelayanan Penumpang Angkutan Laut. 